Article

\title{
Engineering graphitic carbon nitride with expanded interlayer distance for boosting photocatalytic hydrogen evolution
}

\author{
Qiushi Yang a, ${ }^{\dagger}$, Shaonian Hu a, ${ }^{a}$, Yaxuan Yao ${ }^{b}$, Xiangang Lin a, Haiwei Du a,*, Yupeng Yuan a,c,d,\# \\ a School of Chemistry and Chemical Engineering, Anhui Province Key Laboratory of Chemistry for Inorganic/Organic Hybrid Functionalized Materials, \\ Anhui University, Hefei 230601, Ahhui, China \\ b Center for Advanced Measurement Science, National Institute of Metrology, Beijing 100029, China \\ c Key Laboratory of Structure and Functional Regulation of Hybrid Materials (Anhui University), Ministry of Education, Hefei 230601, Anhui, China \\ d Energy Materials and Devices Key Lab of Anhui Province for Photoelectric Conversion, , Anhui University, Hefei 230601, Anhui, China
}

\section{A R T I C L E I N F O}

Article history:

Received 24 March 2020

Accepted 5 May 2020

Published 5 January 2021

\section{Keywords:}

Graphitic carbon nitride

Interlayer distance

Microwave-assisted heating

Photocatalytic hydrogen evolution

\begin{abstract}
A B S T R A C T
Regulating interlayer distance is a crucial factor in the development of two-dimensional (2D) nanomaterials. A 2D metal-free photocatalyst, such as graphitic carbon nitride $\left(\mathrm{g}-\mathrm{C}_{3} \mathrm{~N}_{4}\right)$, exhibits morphology- and microstructure-dependent photocatalytic activity. Herein, we report a straightforward and facile route for the preparation of unique lamellar $\mathrm{g}-\mathrm{C}_{3} \mathrm{~N}_{4}$, by co-firing melamine and ammonium chloride via microwave-assisted heating. Through the decomposition of $\mathrm{NH}_{4} \mathrm{Cl}$, the evaporation of $\mathrm{NH}_{3}$ gas can effectively overcome van der Waals forces, expanding the interlayer distance of g- $\mathrm{C}_{3} \mathrm{~N}_{4}$, thereby creating a lamellar structure consisting of nanosheets. Compared with bulk g- $\mathrm{C}_{3} \mathrm{~N}_{4}$, the $\mathrm{NH}_{3}$-derived lamellar g- $\mathrm{C}_{3} \mathrm{~N}_{4}$ exhibits a larger specific surface area and enhanced optical absorption capability, which increase photocatalytic hydrogen production because of the highly active structure, excellent utilization efficiency of photon energy, and low recombination efficiency of photogenerated charge carriers. This study provides a simple strategy for the regulation of the g- $\mathrm{C}_{3} \mathrm{~N}_{4}$ microstructure toward highly efficient photocatalytic applications.
\end{abstract}

(C) 2021, Dalian Institute of Chemical Physics, Chinese Academy of Sciences. Published by Elsevier B.V. All rights reserved.

\section{Introduction}

The global energy crisis and environmental contamination present the human population with profound challenges, and as such there is an urgent need to develop sustainable, cost-effective and highly efficient technologies for the large-scale production of clean and renewable energy resources. By utilizing semiconductor nanocatalysts, photocatalytic water electrolysis has experienced considerable progress in solar-hydrogen energy conversion [1]. With various advantages, such as a tunable electronic structure, visible-light activity, nontoxicity, facile synthesis as well as chemical stability, graphitic carbon nitride $\left(\mathrm{g}-\mathrm{C}_{3} \mathrm{~N}_{4}\right)$ [2], as a polymeric metal-free semiconductor, has attracted widespread attention and has been extensively studied since the benchmark report [3] introducing it into the photocatalysis research field. The photocatalytic efficiency of bulk g- $\mathrm{C}_{3} \mathrm{~N}_{4}$, however, suffers from a small surface area and a rapid electron-hole recombination

\footnotetext{
* Corresponding author. Tel: +86-551-63861279; Fax: +86-551-63891875; E-mail: haiwei.du@ahu.edu.cn

\# Corresponding author. E-mail: yupengyuan@ahu.edu.cn

† These authors contributed equally to this work.

This work was supported by the National Natural Science Foundation of China (51872003 and 51572003), Anhui Provincial Natural Science Foundation (1908085J21 and 1908085QB83), the University Natural Science Research Project of Anhui Province (KJ2017A299), and the Research Start-up Fund of Anhui University (S020118002/011). DOI: 10.1016/S1872-2067(20)63611-7 | http://www.sciencedirect.com/science/journal/18722067 | Chin. J. Catal., Vol. 42, No. 1, January 2021
} 
rate, which hinder its practical application. The numerous strategies for the enhancement ofg- $\mathrm{C}_{3} \mathrm{~N}_{4}$ photocatalytic activity can be classified according to the following aspects. Firstly, from the viewpoint of catalyst microstructure design, one can endow $\mathrm{g}-\mathrm{C}_{3} \mathrm{~N}_{4}$ with various morphologies to achieve a large surface area, typically via physical and chemical exfoliation of g- $\mathrm{C}_{3} \mathrm{~N}_{4}$ to nanosheets [4-6]. For example, thermal treatment under an $\mathrm{NH}_{3}$ atmosphere is found to effectively synthesizeporous $\mathrm{g}-\mathrm{C}_{3} \mathrm{~N}_{4}$ nanosheets [7]. The reduced thickness and size of the nanosheets resulting from exfoliation facilitate the transport of photogenerated charge carriers from the bulk to the catalyst surface. Secondly, improving crystallinity is a critical factor, as the degree of $\mathrm{g}-\mathrm{C}_{3} \mathrm{~N}_{4}$ crystallinity is essentially associated with the degree of long-range order of the atomic network, which directly affects charge transport behavior. Thirdly, structural modifications [8], such as increasing crystallinity [9], heteroatom doping [10-12], defect creation (C or $\mathrm{N}$ vacancies) inside the crystal lattice [13], embedding metallic single atoms [14], and decorating with transition-metal-based co-catalysts [15-17] can effectively influence the local atomic configuration, coordination condition and electronic structure of g- $\mathrm{C}_{3} \mathrm{~N}_{4}$, thereby further modulating its physicochemical properties.

For the synthesis of $\mathrm{g}-\mathrm{C}_{3} \mathrm{~N}_{4}$ photocatalysts, thermal condensation of N-rich precursors is a commonly used approach, while photocatalytic efficiency can be further increased by means of advanced synthetic strategies [18]. On the one hand, one can modulate the heating conditions, such as reaction atmosphere and temperature, or replace conventional heating with advanced technology, such as microwave-assisted heating [19-21]. Given that the temperature can be elevated in excess of $1000 \mathrm{~K}$ with a rapid heating rate [22], microwave-assisted heating provides sufficient energy for the supramolecular copolymerization, as well as effectively avoids the possible volatilization of respective components, which is a common occurrence with traditional heating methods $[19,20]$. On the other hand, mixing raw precursors with various molten salts, ionic liquids and monomers reportedly improves the photocatalytic activity of $\mathrm{g}-\mathrm{C}_{3} \mathrm{~N}_{4}$. For example, ammonium halides have recently been utilized in the polymerization process of $\mathrm{C}$ - and $\mathrm{N}$-containing precursors [23-27]. Serving as gas soft-templates, gas evaporation during the decomposition of ammonium halides is favorable for creating microporous/mesoporous nanostructures [26]. More importantly, gas evaporation can overcome the weak van de Waals forces between the $\mathrm{g}-\mathrm{C}_{3} \mathrm{~N}_{4}$ layers, to form a highly-active lamellar structure due to the exfoliation effect. The above-mentioned studies, however, have predominantly relied on conventional heating, which renders the synthetic process time-consuming.

Herein, we report a facile one-spot synthesis of g- $\mathrm{C}_{3} \mathrm{~N}_{4}$ photocatalysts via microwave-assisted heating of melamine and $\mathrm{NH}_{4} \mathrm{Cl}$. Compared with bulk g- $\mathrm{C}_{3} \mathrm{~N}_{4}$, prepared by simply heating melamine, the introduction of $\mathrm{NH}_{4} \mathrm{Cl}$ generates a lamellar structure consisting of nanosheets, due to $\mathrm{NH}_{3}$ evaporation during $\mathrm{NH}_{4} \mathrm{Cl}$ decomposition. Consequently, several desired effects were achieved, such as expanded specific surface area, enhanced light harvesting, as well as accelerated charge sepa- ration, collectively resulting in a photocatalytic hydrogen generation rate of lamellar $\mathrm{g}-\mathrm{C}_{3} \mathrm{~N}_{4}$ that was five times higher than that of the bulk counterpart.

\section{Experimental}

Representative synthesis of g-CN- $x$ catalysts: melamine and $\mathrm{NH}_{4} \mathrm{Cl}$ (total mass: $3 \mathrm{~g}$, with $\mathrm{NH}_{4} \mathrm{Cl}$ mass ratios of $0 \mathrm{wt} \%, 9 \mathrm{wt} \%$, $11 \mathrm{wt} \%$, and $16 \mathrm{wt} \%$ ) were pulverized and transferred into a $20 \mathrm{~mL}$ alumina crucible, and then covered with a second alumina crucible (volume: $40 \mathrm{~mL}$ ). The gap between the crucibles was filled with asbestos. The crucible was then buried with $\mathrm{CuO}$ powder in a $40 \mathrm{~mL}$ alumina crucible. Next, the crucibles were heated using a microwave oven (M1-L213B, Midea Group, China) with a power of $700 \mathrm{~W}$ for $20 \mathrm{~min}$, and the catalyst powder was collected after cooling to room temperature. The as-synthesized catalysts were denoted as g-CN- $x$ (g-CN, g-CN-9, g-CN-11 and g-CN-16), where $x$ denotes the mass ratio of $\mathrm{NH}_{4} \mathrm{Cl}$. The role of $\mathrm{NH}_{4} \mathrm{Cl}$ in expanding layer distance was schematically shown in Fig. 1a.

Characterization: X-ray diffraction (XRD) was measured on a DX-2700X-ray diffractometer using $\mathrm{Cu} K_{\alpha 1}$ radiation. The morphology was observed by field-emission scanning electron microscopy (FESEM, Hitachi S-4800), transmission electron microscopy (TEM, JEM-2100) and atomic force microcopy (AFM, Bruker MultiMode V). Fourier transform infrared (FTIR) spectra were recorded on a Vertex80+Hyperion2000 spectrometer. UV-Vis diffuse reflectance spectra (DRS) were collected on a HITACHI3900 UV-Vis spectrophotometer, using $\mathrm{BaSO}_{4}$ as a reflectance standard. Photoluminescence (PL) measurements were carried out on a HITACHI F-4600 fluorometer. The Brunauer-Emmett-Teller (BET) surface area and pore-size distribution of the catalysts were measured by nitrogen adsorption-desorption isotherms (TriStar II, Micromeritics).

Photocatalytic $\mathrm{H}_{2}$ generation testing: The photocatalytic reaction was measured in a $70 \mathrm{~mL}$ closed Pyrex reactor with a quartz window. First, $10 \mathrm{mg}$ of photocatalyst was dispersed in $20 \mathrm{~mL} 10 \mathrm{vol} \%$ triethanolamine (TEOA) solution, and $106 \mu \mathrm{L}$ $\mathrm{H}_{2} \mathrm{PtCl}_{6} \cdot 6 \mathrm{H}_{2} \mathrm{O}$ was then added, introducing $\mathrm{Pt}$ as a co-catalyst. Then, argon was bubbled through the solution with magnetic stirring for $20 \mathrm{~min}$ to remove residual air. Photocatalytic hydrogen production was accomplished by irradiating the suspension with a $300 \mathrm{~W}$ xenon lamp coupled with a UV cut-off filter $(\lambda \geq 420 \mathrm{~nm})$. The gas products were analyzed through a gas chromatograph (GC-1690, Kexiao, China) connected to a TCD detector.

Photoelectrochemical testing: Photoelectrochemical measurements were conducted using an electrochemical workstation (CHI-660E, Chenhua Instruments, China) connected to a three-electrode system, in which an $\mathrm{Ag} / \mathrm{AgCl}$ electrode (containing statured $\mathrm{KCl}$ solution), platinum (Pt) foil, and catalyst-coated carbon paper were employed as the reference, counter and working electrodes, respectively. The electrolyte was $0.1 \mathrm{M} \mathrm{Na}_{2} \mathrm{SO}_{4}$ solution. To prepare the working electrode, 5 mg catalyst was dispersed in $1 \mathrm{~mL}$ mixed solution (volume ratio of water/ethanol/Nafion (5 wt\%) was 490: 490: 20), and 
then ultrasonically treated for $1 \mathrm{~h}$ to form a uniform ink. Next, $20 \mu \mathrm{L}$ of the resultant ink was dropped onto the carbon paper. The electrochemical impedance spectra (EIS) were recorded at a frequency range from $0.01 \mathrm{~Hz}$ to $0.1 \mathrm{MHz}$. Mott-Schottky testing was performed with an amplitude of $5 \mathrm{mV}$ and a frequency of $1 \mathrm{kHz}$.

\section{Results and discussion}

The microstructure and morphology of the as-synthesized g-CN- $x$ catalysts were observed by SEM. As shown in Fig. 1b, the heating of melamine on its own results in an irregular bulk structure, composed of several solid agglomerates of varying sizes. With the introduction of $\mathrm{NH}_{4} \mathrm{Cl}$, the morphology of the catalysts changes significantly. Unlike g-CN, catalysts g-CN-9 and g-CN-11, prepared by the copolymerization with $\mathrm{NH}_{4} \mathrm{Cl}$, exhibit a lamellar structure composed of nanosheets (Fig. 1c and d). This morphology evolution is attributed to the decom- position of $\mathrm{NH}_{4} \mathrm{Cl}$, because the gaseous pressure generated during the decomposition process can overcome the van der Waals forces between the $\mathrm{g}-\mathrm{C}_{3} \mathrm{~N}_{4}$ layers [24], thereby expanding the $\mathrm{g}-\mathrm{C}_{3} \mathrm{~N}_{4}$ interlayer distance, and resulting in a successful exfoliation. The morphology of g-CN-16, however, changes from uniform nanosheets to agglomerated blocks, covered by a little amount of liquid phase (Fig. 1e). The disappearance of nanosheets is attributed to the excessive amount of $\mathrm{NH}_{4} \mathrm{Cl}$, which results in a melting effect due to the relatively low melting point of $\mathrm{NH}_{4} \mathrm{Cl}\left(338^{\circ} \mathrm{C}\right)$. AFM characterization was conducted in order to measure the thickness of g-CN-11, being approximately 15-25 nm, as shown in Figure 1f-h. For further examination of the morphology change induced by microwave-assisted heating with $\mathrm{NH}_{4} \mathrm{Cl}$, nitrogen adsorption-desorption isotherms were measured and the results are presented in Fig. 1i and Table 1. Both g- $\mathrm{CN}$ and g-CN-11 exhibit similar type IV isotherms and type $\mathrm{H} 3$ hysteresis loops, which can be considered as direct evidence of stacking plate-like na-
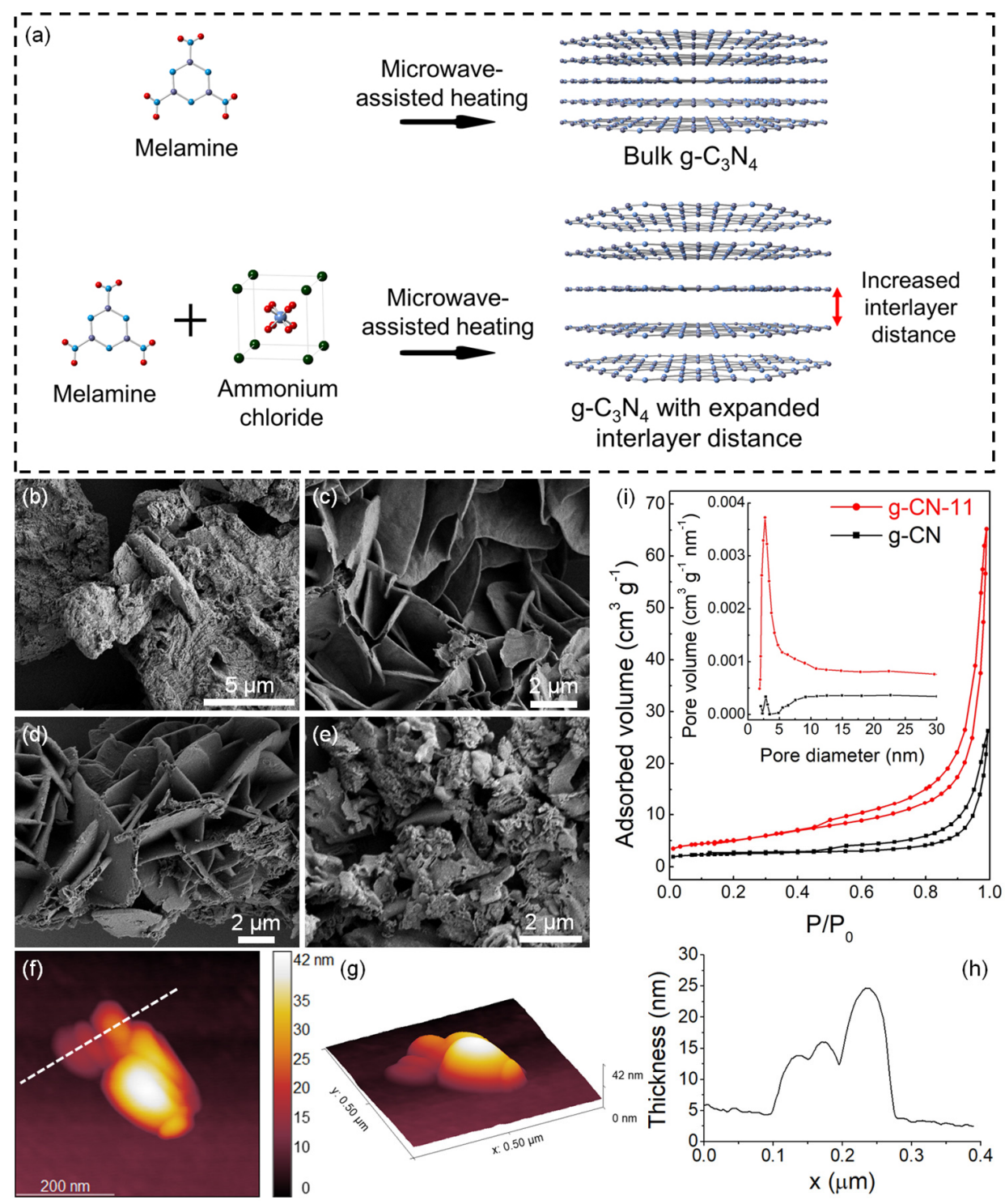

Fig. 1. (a) Schematic illustration of lamellar g- $\mathrm{C}_{3} \mathrm{~N}_{4}$ prepared by copolymerization of melamine and $\mathrm{NH}_{4} \mathrm{Cl}$. SEM images of (b) g-CN, (c) g-CN-9, (d) g-CN-11 and (e) g-CN-16. (f, g, h) AFM image and the corresponding height profile of g-CN-11. (i) Nitrogen adsorption-desorption isotherms and pore size distributions of g-CN and g-CN-11. 
Table 1

BET surface area, pore size and pore volume of the g-CN- $x$ catalysts.

\begin{tabular}{lccc}
\hline Samples & $\begin{array}{c}\text { Surface area } \\
\left(\mathrm{m}^{2} / \mathrm{g}\right)\end{array}$ & $\begin{array}{c}\text { Desorption average pore } \\
\text { size }(\mathrm{nm})\end{array}$ & $\begin{array}{c}\text { Pore volume } \\
\left(\mathrm{cm}^{3} / \mathrm{g}\right)\end{array}$ \\
\hline g-CN & 8.37 & 19.73 & 0.04 \\
g-CN-9 & 13.36 & 21.30 & 0.10 \\
g-CN-11 & 17.90 & 16.40 & 0.10 \\
g-CN-16 & 12.64 & 39.71 & 0.14 \\
\hline
\end{tabular}

noparticles [28]. Among the catalysts tested, the specific surface area of g-CN-11 (17.90 $\left.\mathrm{m}^{2} \mathrm{~g}^{-1}\right)$ exhibited the highest increase (2.14-fold) compared with its bulk g-CN counterpart $\left(8.37 \mathrm{~m}^{2} \mathrm{~g}^{-1}\right)$. The enlarged surface area was attributed to residual pores and the expansion of the interlayer distance between g- $\mathrm{C}_{3} \mathrm{~N}_{4}$ layers occurring during the polymerization process of melamine and ammonium chloride. Furthermore, g-CN-11 exhibited a narrower pore size distribution compared to g-CN, centered at $\sim 2.6 \mathrm{~nm}$ (inset in Fig. 1i), corresponding to the inner cavity of nanosheets, as a characteristic of mesoporous nanostructures. Considering the SEM and AFM images, the exfoliated nanosheet structure and smaller pore size are the most likely factors leading to surface area enhancement. Overall, the variation in surface area is consistent with morphology evolution, indicating that an optimal amount of $\mathrm{NH}_{4} \mathrm{Cl}$ precursor is conducive to promoting $\mathrm{g}-\mathrm{C}_{3} \mathrm{~N}_{4}$ exfoliation.

Figure $2 \mathrm{a}$ and $\mathrm{b}$ represent the XRD patterns of the g-CN- $X$ catalysts prepared with varying amounts of the $\mathrm{NH}_{4} \mathrm{Cl}$ precursor. The catalysts all exhibit a graphitic structure with two typical peaks located at approximately $13^{\circ}$ and $27^{\circ}$, corresponding to the in-plane repeating units, and the periodic graphitic stacking of the conjugated $\mathrm{C}-\mathrm{N}$ atomic layers, respectively. The analogous diffraction patterns indicate that the crystal structure of $\mathrm{g}-\mathrm{C}_{3} \mathrm{~N}_{4}$ is well preserved following the introduction of $\mathrm{NH}_{4} \mathrm{Cl}$. The co-pyrolysis of melamine with $\mathrm{NH}_{4} \mathrm{Cl}$, however, does result in certain structural changes in the catalysts. On the one hand, the (002) diffraction peaks of $\mathrm{NH}_{4} \mathrm{Cl}$-modified samples show a decrease in the peak intensity, becoming marginally broader in comparison to those of the bulk g-CN, suggesting a decreased long-range structural order, which is attributed to a lower degree of stacking of the $\mathrm{C}-\mathrm{N}$ atomic layer along the $\mathrm{z}$ direction. On the other hand, the enlarged patterns of the (002) peaks (Fig. 2b) clearly exhibit a peak shift towards lower angles, indicating a larger interlayer distance between the $\mathrm{g}-\mathrm{CN}-X$ layers, according to Bragg's law $n \lambda=2 \mathrm{~d} \sin \theta$. Overall, these fea-
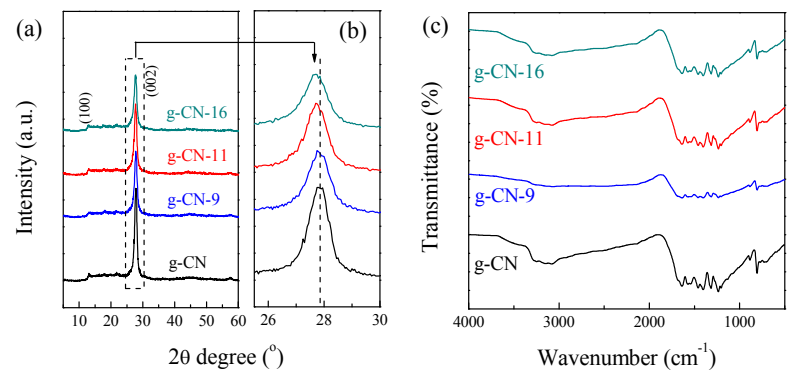

Fig. 2. XRD patterns: (a) wide range and (b) enlarged patterns of (002) peaks. (c) FTIR spectra of $\mathrm{g}-\mathrm{CN}-x$.
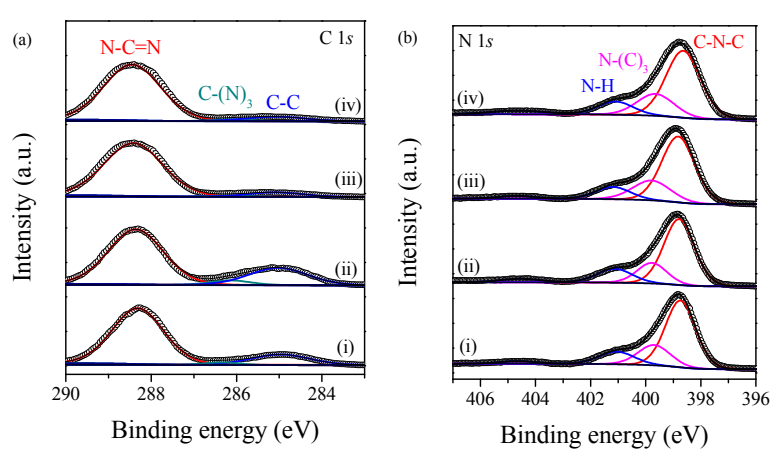

Fig. 3. (a) XPS C $1 s$ and (b) $\mathrm{N} 1 s$ spectra: (i) g-CN, (ii) g-CN-9, (iii) g-CN-11 and (iv) g-CN-16.

tures reflect a decreased degree of interlayer periodicity due to diminished van der Waals interactions, originating from the exfoliation of g- $\mathrm{C}_{3} \mathrm{~N}_{4}$ layers [29], as $\mathrm{NH}_{3}$ etching [7] and $\mathrm{Cl}^{-}$intercalation [30] can occur simultaneously during the decomposition of $\mathrm{NH}_{4} \mathrm{Cl}$ [26]. The phase structure of the g-CN- $x$ catalysts was analyzed by FTIR spectrometry. As depicted in Fig. 2c, the FTIR spectra exhibit characteristic bands of g- $\mathrm{C}_{3} \mathrm{~N}_{4}$, such as the $\mathrm{N}-\mathrm{H}$ vibrational mode $\left(3000-3600 \mathrm{~cm}^{-1}\right)$, aromatic C-N heterocyclic stretching (1200-1800 $\left.\mathrm{cm}^{-1}\right)$, as well as the mode of the tri-s-triazine units $\left(\sim 800 \mathrm{~cm}^{-1}\right)$. No distinct alterations were detected in the FTIR spectra with increasing amounts of $\mathrm{NH}_{4} \mathrm{Cl}$, indicating that melamine- $\mathrm{NH}_{4} \mathrm{Cl}$ polymerization does not destroy the graphitic C-N network structure of the g- $\mathrm{C}_{3} \mathrm{~N}_{4}$ catalysts.

In order to study the elemental composition, XPS characterizations were conducted and the chemical states were analyzed by curve fitting. Carbon, nitrogen and oxygen were detected exclusively in the g-CN- $x$ catalysts (Fig. S2 and Table S1). In the case of the $\mathrm{C} 1 s$ spectra (Fig. 3a), three XPS peaks located at $284.9 \mathrm{eV}, 286.1 \mathrm{eV}$ and $288.4 \mathrm{eV}$ were detected, corresponding to $\mathrm{C}-\mathrm{C}, \mathrm{C}-(\mathrm{N})_{3}$ and $\mathrm{N}-\mathrm{C}=\mathrm{N}$, respectively. The changes in the peak ratios are consistent with the elemental compositions and $\mathrm{C} / \mathrm{N}$ ratios. In the high-resolution $\mathrm{N} 1 \mathrm{~s}$ spectra (Fig. 3b), the three peaks at 398.7, 399.7 and $401.0 \mathrm{eV}$ were ascribed to the $\mathrm{sp}^{2}$ nitrogen $\mathrm{C}-\mathrm{N}-\mathrm{C}$, tertiary nitrogen $\mathrm{N}-(\mathrm{C})_{3}$ and the $\mathrm{N}-\mathrm{H}$ from the terminal amino group. The peak ratio of $\mathrm{C}-\mathrm{N}-\mathrm{C}: \mathrm{N}-(\mathrm{C})_{3}$ is inversely linked to the degree of polymerization [31]. In the present study, g-CN-11 and g-CN-16 exhibited the lowest ratios (Table S1), indicating that polymerization can be optimized by modulating the $\mathrm{NH}_{4} \mathrm{Cl}$ content.

Photocatalytic activity was evaluated by measuring hydrogen production in a Pyrex reactor with a quartz window under the irradiation of a $300 \mathrm{~W}$ xenon lamp with a UV cut-off filter $(\lambda$ $\geq 420 \mathrm{~nm}$ ). During the reaction, Pt and TEOA were added as the co-catalyst and sacrificial agent, respectively. As shown in Fig. $4 \mathrm{a}$ and $\mathrm{b}$, the catalysts tested were all active for photocatalytic $\mathrm{H}_{2}$ evolution and the activity was strongly dependent on $\mathrm{NH}_{4} \mathrm{Cl}$ content. The bulk g-CN catalyst exhibited low $\mathrm{H}_{2}$ production (4.67 $\mu \mathrm{mol} \mathrm{h}{ }^{-1}$ ), while evidently, melamine- $\mathrm{NH}_{4} \mathrm{Cl}$ polymerization promoted $\mathrm{H}_{2}$ production activity, the highest being that of the $11 \mathrm{wt} \% \mathrm{NH}_{4} \mathrm{Cl}$, which compared to the bulk, exhibited a five-fold increase in the $\mathrm{H}_{2}$ production rate $\left(23.6 \mu \mathrm{mol} \mathrm{h} \mathrm{h}^{-1}\right)$. 

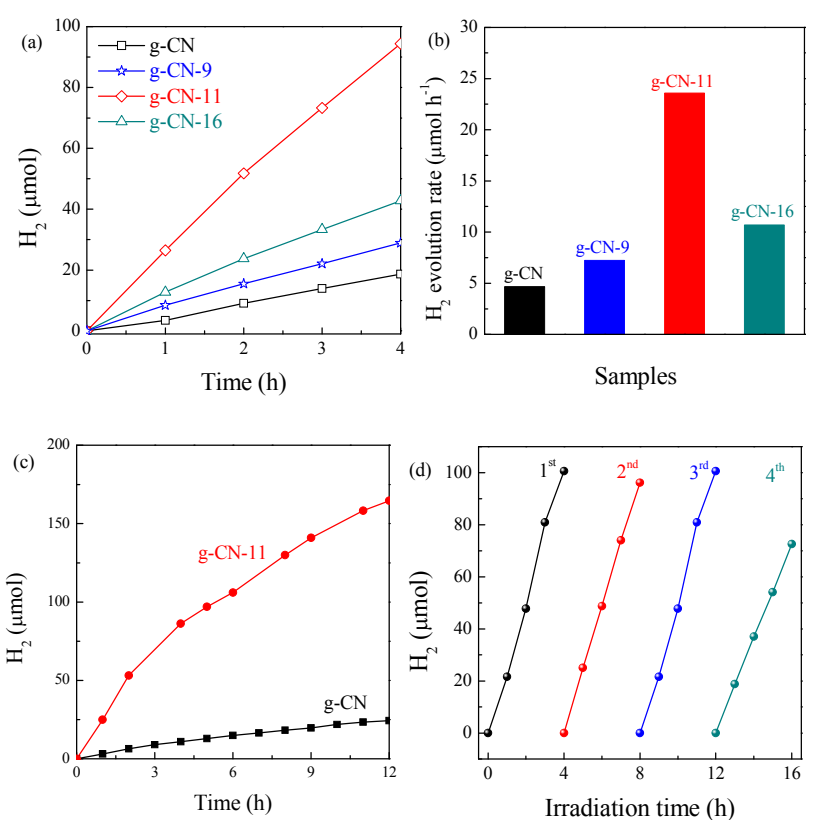

Fig. 4. (a) $\mathrm{H}_{2}$ production with time and (b) $\mathrm{H}_{2}$ generation rates of g-CN- $X$ catalysts. (c) Long-term $\mathrm{H}_{2}$ production of g-CN and g-CN-11. (d) Cyclic $\mathrm{H}_{2}$ production of g-CN-11.

Excessive amounts of $\mathrm{NH}_{4} \mathrm{Cl}$, however, reduced the photocatalytic activity and $\mathrm{H}_{2}$ generation. These results indicate that by employing a suitable amount of $\mathrm{NH}_{4} \mathrm{Cl}$ the photocatalytic performance of g-CN catalysts can be significantly enhanced, while reduced light absorption resulting from excessive amounts of $\mathrm{NH}_{4} \mathrm{Cl}$ deteriorates the $\mathrm{H}_{2}$ production activity (will be discussed later). As mentioned, polymerization with $\mathrm{NH}_{4} \mathrm{Cl}$ results in a mesoporous nanostructure of the g-CN-11 catalyst, which not only increases the surface area, but additionally promotes optical absorption. In addition, g-CN-11 was selected to examine the stability and recyclability of the system, by performing cycling tests under one reaction condition. The long-term hydrogen production exhibits a near-linear relationship with irradiation time (Fig. 4c). A minimal reduction in $\mathrm{H}_{2}$ generation is observed after four runs (Fig. 4d); this is likely due to the continuous consumption of TEOA [32], or the presence of $\mathrm{H}_{2} \mathrm{O}_{2}$, which poisons the catalyst [33]. The nanosheet structure of the g-CN-11 catalyst remained intact following the photocatalytic tests (Fig. S1).

As the light absorption of photocatalysts can be significantly influenced by structural and morphological alterations, the optical absorption capability of g-CN- $x$ catalysts was evaluated by UV-vis diffuse reflectance spectroscopy. In addition, the effect of $\mathrm{NH}_{4} \mathrm{Cl}$ decomposition on band structure and position was examined. As evident in Fig. 5a, the absorption edges of the g-CN- $x$ catalysts are extended towards the visible light range, with enhanced absorption intensity after polymerization with a small amount of $\mathrm{NH}_{4} \mathrm{Cl}$. In particular, g-CN-11 exhibits a markedly enhanced light harvesting capability because of the mesoporous framework, with multiple scattering effects being observed for the ammonia gas-derived lamellar structure [34,35]. Accordingly, the band gaps determined from the Tauc plots
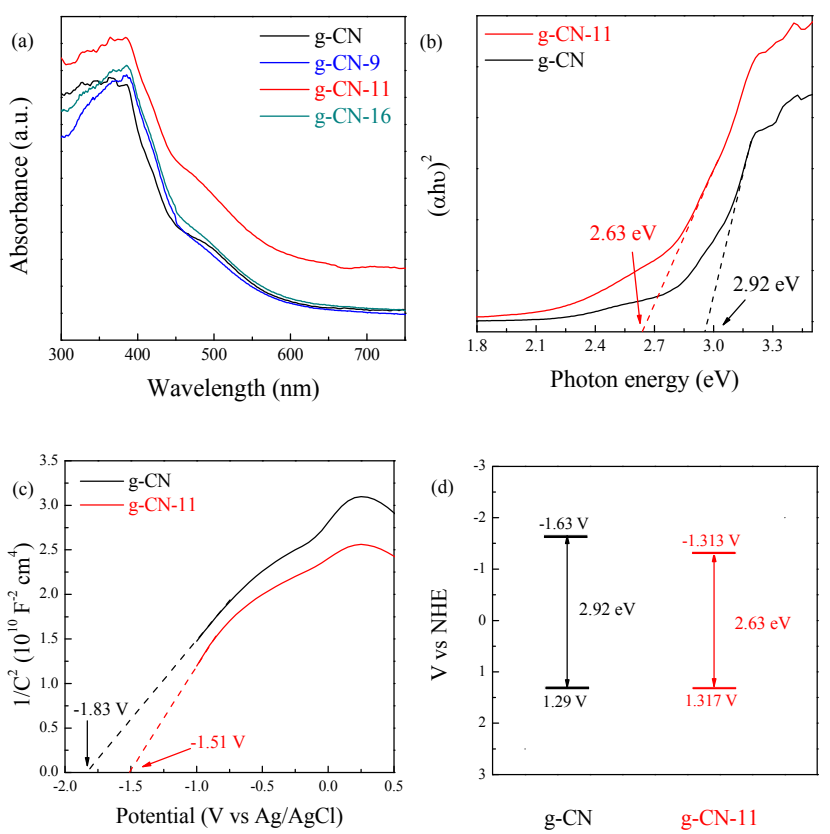

Fig. 5. (a) UV-vis diffuse reflectance spectra of g-CN- $x$ catalysts. (b) Plots of $(\alpha h v)^{2}$ vs $h v$, (c) Mott-Schottky plots and (d) band energy diagram for g-CN and g-CN-11 photocatalysts.

(Fig. 5b) were $2.92 \mathrm{eV}$ for g-CN, and $2.63 \mathrm{eV}$ for g-CN-11, due to the size reduction resulting from the morphology transformation from the bulk to the lamellar structure [36]. To determine the flat band potential [37], the Mott-Schottky plots (Fig. $5 c)$ were recorded by electrochemical measurements in $0.1 \mathrm{M}$ $\mathrm{Na}_{2} \mathrm{SO}_{4}$ solution. The flat band potentials (the intercept of the Mott-Schottky plots) of g-CN and g-CN-11 were $-1.83 \mathrm{~V}$ and $-1.51 \mathrm{~V}$, respectively, vs. an $\mathrm{Ag} / \mathrm{AgCl}$ electrode $(-1.63 \mathrm{~V}$ and $-1.313 \mathrm{~V}$ vs. NHE, respectively), approximating the bottom of the conduction band. Combining the band gap from the UV/vis absorption spectra, the band energy position is shown in Fig. $5 \mathrm{~d}$, which indicates that the band structure for g-CN-11 is theoretically more feasible for hydrogen evolution than that of g-CN.

In order to confirm the contribution of light absorption to the enhancement of photocatalytic activity, the hydrogen production of g-CN-11 was evaluated under light irradiation of varying wavelengths. As shown in Fig. 6a, the photocatalytic activity is well matched with the optical absorption, and continues to be observed above $510 \mathrm{~nm}$, suggesting that the increase in the number of harvested photons, stemming from the extension of visible light absorption is the intrinsic driving force enabling enhanced $\mathrm{H}_{2}$ evolution [23]. In order to verify and rationalize the enhanced hydrogen evolution activity, steady-state PL spectra and EIS spectra were recorded, to study the charge transfer and carrier recombination rate of the photogenerated electron-hole carriers. It is well accepted that a lower PL emission intensity in steady-state PL spectra is associated with a prolonged lifetime of electron-hole carriers, corresponding to a higher separation efficiency. As shown in Fig. $6 \mathrm{~b}$, the fluorescence intensity of g-CN at $\sim 465 \mathrm{~nm}$ is signifi- 

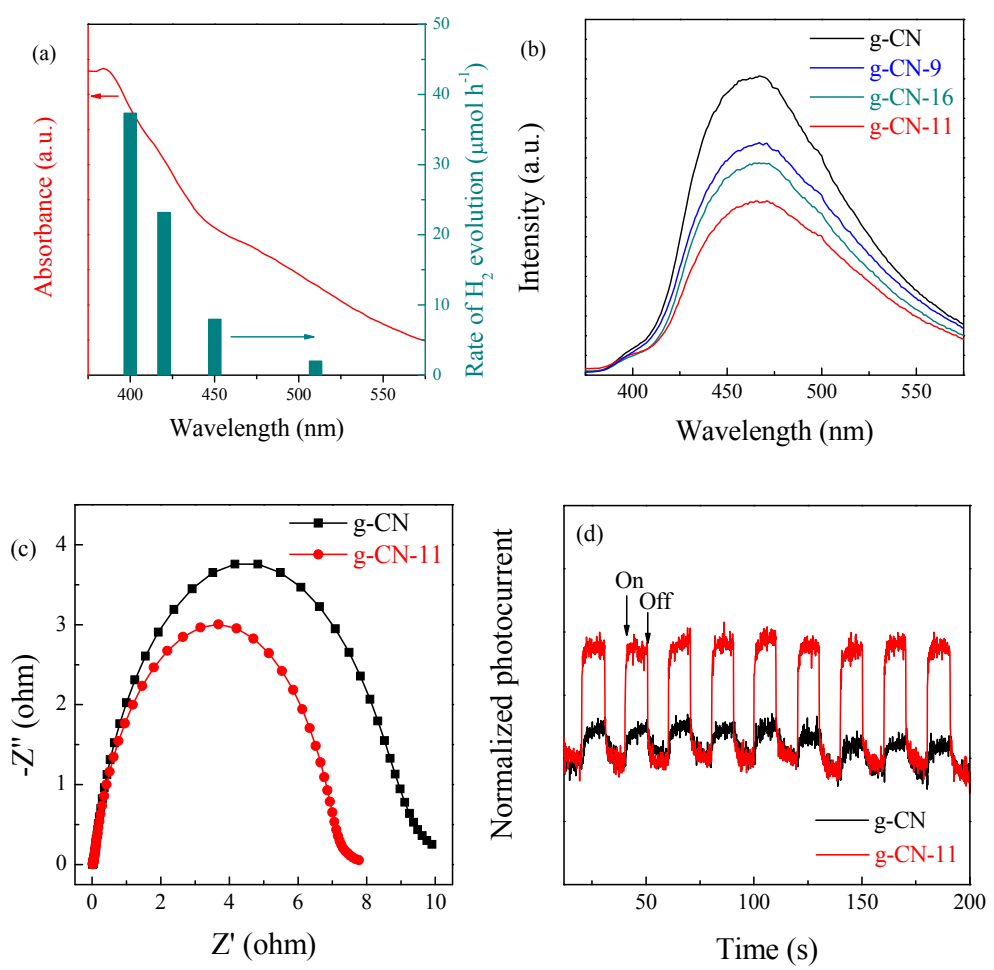

Fig. 6. (a) Wavelength dependence of the $\mathrm{H}_{2}$ evolution rate for g-CN-11, (b) steady-state PL spectra, (c) electrochemical impedance spectra, and (d) photocurrent response of g-CN and g-CN-11 catalysts.

cantly reduced after polymerization with $\mathrm{NH}_{4} \mathrm{Cl}$; g-CN-11 exhibits a PL quenching performance with the lowest intensity, indicating a suppressed recombination of photogenerated electron-hole pairs and a more efficient carrier separation. Fig. $6 \mathrm{c}$ compares the EIS spectra of the g-CN and g-CN-11 catalysts. In contrast to g-CN, g-CN-11 exhibits a smaller semicircle radius in the low-frequency region, indicating a smaller charge transfer resistance $[38,39]$. The lower recombination efficiency of g-CN-11 was additionally confirmed by the photocurrent test (Fig. 6d), as g-CN-11 demonstrates higher on/off photoresponse sensitivity compared with bulk g-CN. On the basis of these results, it can be concluded that the lamellar structure resulting from polymerization with an optimal amount of $\mathrm{NH}_{4} \mathrm{Cl}$ enables enhanced photocatalytic $\mathrm{H}_{2}$ production over $\mathrm{g}-\mathrm{C}_{3} \mathrm{~N}_{4}$.

\section{Conclusions}

In summary, we report a one-step synthesis of $\mathrm{g}-\mathrm{C}_{3} \mathrm{~N}_{4}$ nanosheets by copolymerization of melamine and $\mathrm{NH}_{4} \mathrm{Cl}$ via microwave-assisted heating. The decomposition of $\mathrm{NH}_{4} \mathrm{Cl}$ can effectively generate gaseous pressure to overcome van der Waals forces, and thereby expand the g- $\mathrm{C}_{3} \mathrm{~N}_{4}$ interlayers, which results in a lamellar structure consisting of nanosheets with an enlarged specific surface area and enhanced optical absorption. In comparison to its bulk g- $\mathrm{C}_{3} \mathrm{~N}_{4}$ counterpart, lamellar g- $\mathrm{C}_{3} \mathrm{~N}_{4}$ exhibits enhanced light absorption, a lower recombination efficiency of photogenerated charge carriers, as well as a superior charge transfer, giving rise to a five-fold increase in its photocatalytic hydrogen production rate.

\section{References}

[1] S. Chen, T. Takata, K. Domen, Nat. Rev. Mater., 2017, 2, 17050.

[2] Y. Ren, D. Zeng, W.-J. Ong, Chin. J. Catal., 2019, 40, 289-319.

[3] X. Wang, K. Maeda, A. Thomas, K. Takanabe, G. Xin, J. M. Carlsson, K. Domen, M. Antonietti, Nat. Mater., 2009, 8, 76-80.

[4] J. Ji, J. Wen, Y. Shen, Y. Lv, Y. Chen, S. Liu, H. Ma, Y. Zhang, J. Am. Chem. Soc., 2017, 139, 11698-11701.

[5] L. Cui, X. Hou, H. Du, Y. Yuan, Appl. Surf. Sci., 2020, 501, 144259.

[6] W. Ding, S. Liu, Z. He, Chin. J. Catal., 2017, 38, 1711-1718.

[7] Q. Liang, Z. Li, Z. H. Huang, F. Kang, Q. H. Yang, Adv. Funct. Mater., 2015, 25, 6885-6892.

[8] Y. Zheng, L. Lin, B. Wang, X. Wang, Angew. Chem. Int. Ed., 2015, 54, 12868-12884.

[9] Y. Li, D. Zhang, X. Feng, Q. Xiang, Chin. J. Catal., 2020, 41, 21-30.

[10] J. Jiang, S. Cao, C. Hu, C. Chen, Chin. J. Catal., 2017, 38, 1981-1989.

[11] E.-X. Han, Y.-Y. Li, Q.-H. Wang, W.-Q. Huang, L. Luo, W. Hu, G.-F. Huang, J. Mater. Sci. Technol., 2019, 35, 2288-2296.

[12] Q. Yan, G.-F. Huang, D.-F. Li, M. Zhang, A.-L. Pan, W.-Q. Huang, J. Mater. Sci. Technol, 2018, 34, 2515-2520.

[13] X. Li, J. Zhang, F. Zhou, H. Zhang, J. Bai, Y. Wang, H. Wang, Chin. J. Catal., 2018, 39, 1090-1098.

[14] T. Tong, B. Zhu, C. Jiang, B. Cheng, J. Yu, Appl. Surf. Sci., 2018, 433, 1175-1183.

[15] Z. Li, Y. Ma, X. Hu, E. Liu, J. Fan, Chin. J. Catal., 2019, 40, 434-445.

[16] K. He, J. Xie, Z.-Q. Liu, N. Li, X. Chen, J. Hu, X. Li, J. Mater. Chem. A, 2018, 6, 13110-13122.

[17] R. Shen, J. Xie, X. Lu, X. Chen, X. Li, ACS Sustain. Chem. Eng., 2018, 6, 4026-4036.

[18] S. Ye, R. Wang, M.-Z. Wu, Y.-P. Yuan, Appl. Surf. Sci., 2015, 358, $15-27$.

[19] Y.-P. Yuan, L.-S. Yin, S.-W. Cao, L.-N. Gu, G.-S. Xu, P. Du, H. Chai, Y.-S. 


\title{
Graphical Abstract
}

Chin. J. Catal., 2021, 42: 217-224 doi: 10.1016/S1872-2067(20)63611-7

Engineering graphitic carbon nitride with expanded interlayer distance for boosting photocatalytic hydrogen evolution

Qiushi Yang, Shaonian Hu, Yaxuan Yao, Xiangang Lin, Haiwei Du*, Yupeng Yuan*

Anhui University; National Institute of Metrology;

Expanding interlayer distance of graphitic carbon nitride via ammonia gas escape derived by cofiring melamine and ammonium chloride for enhanced photocatalytic hydrogen production activity.

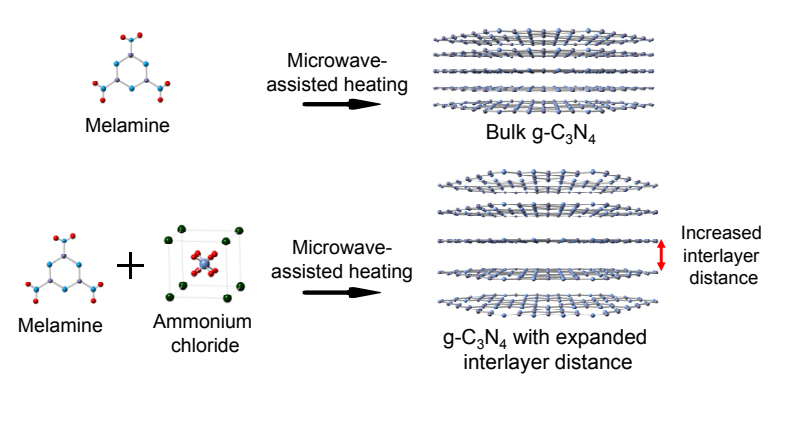

Liao, C. Xue, Green Chem., 2014, 16, 4663-4668.

[20] Y. Guo, J. Li, Y. Yuan, L. Li, M. Zhang, C. Zhou, Z. Lin, Angew. Chem. Int. Ed., 2016, 55, 14693-14697.

[21] J. Li, D. Wu, J. Iocozzia, H. Du, X. Liu, Y. Yuan, W. Zhou, Z. Li, Z. Xue, Z. Lin, Angew. Chem. Int. Ed., 2019, 58, 1985-1989.

[22] M. Baghbanzadeh, L. Carbone, P. D. Cozzoli, C. O. Kappe, Angew. Chem. Int. Ed., 2011, 50, 11312-11359.

[23] G. Zhang, M. Zhang, X. Ye, X. Qiu, S. Lin, X. Wang, Adv. Mater., 2014, 26, 805-809.

[24] H. Xu, J. Yan, X. She, L. Xu, J. Xia, Y. Xu, Y. Song, L. Huang, H. Li, Nanoscale, 2014, 6, 1406-1415.

[25] X. Lu, K. Xu, P. Chen, K. Jia, S. Liu, C. Wu, J. Mater. Chem. A, 2014, 2, 18924-18928.

[26] W. Iqbal, C. Dong, M. Xing, X. Tan, J. Zhang, Catal. Sci. Technol., 2017, 7, 1726-1734.

[27] Z.-A. Lan, G. Zhang, X. Wang, Appl. Catal. B, 2016, 192, 116-125.

[28] K. A. Cychosz, R. Guillet-Nicolas, J. Garcia-Martinez, M. Thommes, Chem. Soc. Rev., 2017, 46, 389-414.

[29] S. Yang, Y. Gong, J. Zhang, L. Zhan, L. Ma, Z. Fang, R. Vajtai, X. Wang,
P. M. Ajayan, Adv. Mater., 2013, 25, 2452-2456.

[30] C. Liu, Y. Zhang, F. Dong, A. Reshak, L. Ye, N. Pinna, C. Zeng, T. Zhang, H. Huang, Appl. Catal. B, 2017, 203, 465-474.

[31] W. Xu, X. An, Q. Zhang, Z. Li, Q. Zhang, Z. Yao, X. Wang, S. Wang, J. Zheng, J. Zhang, W. Wu, M. Wu, ACS Sustain. Chem. Eng., 2019, 7, 12351-12357.

[32] Z. Lin, X. Wang, Angew. Chem. Int. Ed. Engl., 2013, 52, 1735-1738.

[33] J. Liu, Y. Zhang, L. Lu, G. Wu, W. Chen, Chem. Commun., 2012, 48, 8826-8828.

[34] X. Wang, K. Maeda, X. Chen, K. Takanabe, K. Domen, Y. Hou, X. Fu, M. Antonietti, J. Am. Chem. Soc., 2019, 131, 1680-1681.

[35] H. Yan, Chem. Commun., 2012, 48, 3430-3432.

[36] Y. Li, H. Xu, S. Ouyang, D. Lu, X. Wang, D. Wang, J. Ye, J. Mater. Chem. A, 2016, 4, 2943-2950.

[37] K. Gelderman, L. Lee, S. Donne, J. Chem. Educ., 2007, 84, 685-688.

[38] P.-Y. Kuang, P.-X. Zheng, Z.-Q. Liu, J.-L. Lei, H. Wu, N. Li, T.-Y. Ma, Small, 2016, 12, 6735-6744.

[39] R.-B. Wei, Z.-L. Huang, G.-H. Gu, Z. Wang, L. Zeng, Y. Chen, Z.-Q. Liu, Appl. Catal. B, 2018, 231, 101-107.

\section{增大石墨相氮化碳层间距提升光催化制氢性能}

\author{
杨秋实 ${ }^{\mathrm{a}, \dagger}$ ，胡少年 ${ }^{\mathrm{a}, \dagger}$ ，姚雅萱 ${ }^{\mathrm{b}}$ ，林先刚 ${ }^{\mathrm{a}}$ ，杜海威 ${ }^{\mathrm{a},{ }^{*}}$ ，袁玉鹏 $\mathrm{a}, \mathrm{c}, \mathrm{d}, \#$

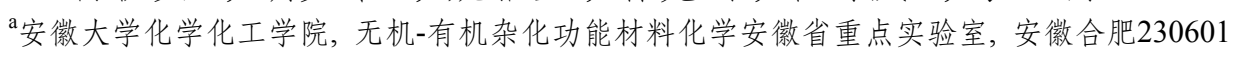 \\ ${ }^{\mathrm{b}}$ 中国计量科学研究院前沿计量科学中心, 北京 100029

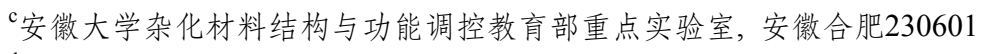 \\ d安徽大学光电转换能源材料与器件安徽省重点实验室, 安徽合肥 230601
}

摘要: 石墨相氮化碳是一类非金属聚合物, 其光催化特性, 特别是在光催化水分解反应中的应用引起了广泛关注. 目前, 块 体石墨相氮化碳的光催化性能主要受比表面积较大、光子利用率较低等因素的制约. 前期大量研究主要采用异质元素掺 杂、负载助催化剂、设计缺陷、构建异质结构等策略来进一步提升光催化性能. 石墨相氮化碳具有二维层状的晶体结构, 理 论上其形貌和显微结构会对光催化性能有显著影响. 因此, 本文从调节材料本征结构这一角度, 报道了一种调控石墨相氮 化碳层间距的方法. 将三聚氰胺和氯化铵混合后, 通过微波快速加热, 利用氯化铵分解过程中释放氨气这一特性, 破坏石 墨相氮化碳层间的范德华力, 增大其层间距并成功获得了薄片状结构. 同时, 微波加热可以实现快速升温, 有效避免了电 炉加热炦烧时间较长导致前驱体挥发的问题. 采用扫描电子显微镜、氮气等温吸脱附曲线、X射线衍射、红外光谱、紫外 -可见吸收光谱、荧光光谱、光催化制氢和电化学测试等表征手段, 研究了不同氯化铵含量对石墨相氮化碳层间距的作用 
以及调控层间距对光催化活性的影响.

通过扫描电子显微镜观察, 与三聚氰胺加热所得到的块状结构相比, 适量的氯化铵(氯化铵质量比为 $11 \%$ )和三聚氰胺 在微波快速加热处理后可以获得薄片状结构. 氮气等温吸脱附曲线进一步证实了显微结构的变化, 薄片状结构和块体结 构相比BET比表面积提升了2.1倍. X射线衍射分析证实随着氯化铵含量的增加, (002)衍射峰位置左移, 意味着层间距逐渐 增大. 红外光谱则没有明显的变化, 说明氯化铵和三聚氭胺共烧并不会改变石墨相氮化碳的化学结构. 光催化制氢测试发 现, 添加适量的氯化铵和三聚氰胺共烧可以明显提升光催化制氢性能. 与块体材料 $\left(4.67 \mu \mathrm{mol} \mathrm{h} \mathrm{h}^{-1}\right)$ 相比, 层间距增大后光催 化活性提升了约 5 倍 $\left(23.6 \mu \mathrm{mol} \mathrm{h}{ }^{-1}\right)$. 结合紫外-可见吸收光谱和电化学莫特肖特基测试, 我们发现层间距增大后可以显著提 升石墨相氮化碳的可见光吸收性质, 减小带宽, 并获得更为合适的能级结构. 且样品的导电性能得到改善, 有利于电荷传 输, 光生电子空穴对的分离效率进一步提升. 以上结果说明调控石墨相氮化碳的层间距是一种简单有效提升催化剂光催 化性能的手段.

关键词: 石墨相氮化碳; 层间距; 微波加热; 光催化制氢

收稿日期: 2020-03-24. 接受日期: 2020-05-05. 出版日期: 2021-01-05.

*通讯联系人. 电话: (0551)63861279; 传真: (0551)63891875; 电子信箱: haiwei.du@ahu.edu.cn

\#通讯联系人. 电子信箱: yupengyuan@ahu.edu.cn

†共同第一作者.

基金来源：国家自然科学基金(51872003，51572003); 安徽省自然科学基金(1908085J21，1908085QB83); 安徽省高校自然科学研 究项目(KJ2017A299); 安徽大学科研启动基金(S020118002/011).

本文的电子版全文由Elsevier出版社在ScienceDirect上出版(http://www.sciencedirect.com/science/journal/18722067). 